ARTICOLE

\title{
INTERPRETĂRI ALE INSTANȚELOR EUROPENE CE VIZEAZĂ DREPTUL LA IDENTITATE AL COPILULUI
}

\author{
DOI:10.24193/SUBBiur.62(2017).3.7 \\ Published Online: 2017-09-30 \\ Published Print: 2017-09-30 \\ Ioana NICOLAE* \\ Georgeta-Bianca SPÎRCHEZ**
}

\begin{abstract}
Interpretations of European Courts concerning the child's right to personal identity. This paper aims to contribute to the knowledge of the relevant aspects that configures the child's right to personal identity. To achieve this goal, we analyzed the main elements of the right to identity content that a child should enjoy, namely: the child's right to name, the right to citizenship, the child's right to know his parents and to be cared for, raised and educated by them. The vectors of our analysis are represented by the jurisprudential guidelines in this field of the European Courts - the European Court of Human Rights and the Court of Justice of the European Union, as well as by the exposure of the most current doctrinal opinions expressed both nationally and internationally.
\end{abstract}

Keywords: the right to identity, right to name, citizenship, affiliation.

Cuvinte cheie: dreptul la identitate, dreptul la nume, cetățenie, filiație.

\section{Introducere}

Prezentul studiu s-a conturat în contextul preocupărilor ce există, nu numai în plan național, dar și internațional, de asigurare a unui mediu propice creșterii și dezvoltării armonioase a copilului. În acest cadru vorbim, în general, de protecția copilului, adică de acel „pachet de măsuri de protecție, asistență și apărare, preconizat de stat și pus în aplicare de organismele sale specializate $\mathrm{cu}$ ajutorul factorilor sociali (organizații neguvernamentale, familie, etc.) în vederea asigurării unui trai decent pentru ființa umană, constând în dezvoltarea sa armonioasă. ${ }^{1}$ Fără îndoială, dincolo de normele edictate de Stat, un reper important ${ }^{2}$, și în această materie, îl constituie interpretările instanțelor europene și ne referim aici la Curtea Europeană a Drepturilor Omului ${ }^{3}$, respectiv la Curtea de Justiție a Uniunii Europene.

În cele ce urmează, nu ne propunem să tratăm întreaga problematică a protecției drepturilor copilului, ci vom supune examinării noastre doar aspectele legate de identitatea personală a copilului. Opțiunea noastră este justificată și de importanța acestui drept, sens în care 
avem în vedere faptul că, așa cum sugestiv s-a stabilit în literatura de specialitate ${ }^{4}$, identitatea unui individ reprezintă afirmarea existenței sale într-o societate şi, totodată, o dimensiune a recunoaștii individualității sale, prin care se diferenţiază faţă de ceilalţi subieç̧i de drept.

Astfel, în plan internațional, la nivelul Convenției Europene a Drepturilor Omului nu vom regăsi prevăzut, distinct, dreptul la identitate, dar vom reține, urmare a cercetării literaturii de specialitate ${ }^{5}$, că acesta face parte din conținutul dreptului la viață privată garantat de art.8 al Convenției 6

La nivelul Uniunii Europene, drepturile copilului fac obiectul de reglementare al art.

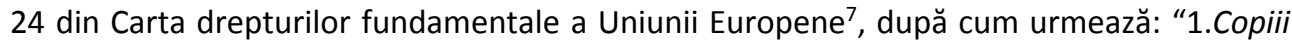
au dreptul la protecția și îngrijirile necesare pentru asigurarea bunăstării lor. Ei își pot exprima în mod liber opinia. Aceasta se ia în considerare în problemele care ii privesc, în funcție de vârsta și gradul lor de maturitate. 2. În toate acțiunile referitoare la copii, indiferent dacă sunt realizate de autorități publice sau de instituții private, interesul superior al copilului trebuie să fie considerat primordial. 3. Orice copil are dreptul de a întreține cu regularitate relații personale și contacte directe cu ambii părinți, cu excepția cazului în care acestea sunt contrare interesului său".

Deși din cele citate mai sus nu se disting dispoziții exprese privitoare la dreptul la identitate al copilului, nici la nivelul Uniunii Europene, astfel cum vom avea prilejul a evidenția, multe din aspectele juridice ale dreptului la identitate sunt interpretate de Curtea de Luxemburg în relație cu libertatea de circulație.

După cum a stabilit doctrina ${ }^{8}$, pornind de la dispoziţiile Convenţiei internaţionale privind drepturile copilului, cele ale Pactului Internaţional cu privire la drepturile civile şi politice şi ale Legii nr. $274 / 2004^{9}$, elementele relevante a fi analizate din conținutul dreptului la identitate al copilului sunt: dreptul copilului la nume, dreptul la cetăţenie, dreptul copilului de a-şi cunoaşte părinţii şi de a fi îngrijit, crescut şi educat de aceştia.

\section{Dreptul copilului la nume}

După cum știm, numele este un mijloc de individualizare a persoanei fizice, sau, așa cum sugestiv s-a exprimat în literatura de specialitate ${ }^{10}$, „numele este $\mathrm{o}$ asociere de cuvinte, care este învestită prin lege cu calitatea de a desemna o anumită persoană fizică, în contextul raporturilor juridice la care aceasta participă".

Din punct de vedere structural, numele cuprinde, în general, numele de familie și prenumele. Astfel, numele de familie se referă la legătura persoanei fizice cu o anumită familie și, de regulă, se dobândește conform legiii ${ }^{11}$, pe când prenumele cuprinde una sau mai multe cuvinte ce se atribuie în mod voluntar de către părinți copiilor lor ${ }^{12}$.

Doctrina ${ }^{13}$ notează că dobândirea unei identități și stabilitatea acelei identități sunt garantate de caracterele juridice ale acestui drept personal nepatrimonial: inalienabilitatea, imprescriptibilitatea, insesizabilitatea, opozabilitatea erga omnes, personalitatea, universalitatea, legalitatea şi unitatea.

Curtea Europeană a Drepturilor Omului a apreciat că alegerea prenumelui unui copil de către părinții săi se încadrează în sfera noțiunii de viață privată iar refuzul unei autorități de a înregistra acel prenume poate constitui o încălcare a art.8 din Convenție ${ }^{14}$. 
În cauza Johansson c. Finlandei ${ }^{15}$, autoritățile cu atribuții în domeniu au refuzat să înregistreze un prenume ales de părinții copilului, motivând că acesta nu corespundea cu procedura de numire de la nivel național. În analiza pe care a realizat-o, Curtea de la Strasbourg a pus în balanță practica națională (adică interesul public de respectare a acestei reglementări pentru a păstra identitatea lingvistică și culturală a statului) și interesul privat de a înregistra copilul cu numele ales. Atâta timp cât a constatat că prenumele ales nu era nepotrivit, ridicol și nu îl prejudicia pe copil, mai mult, putea fi pronunțat în limba țării și fusese înregistrat în sistemul de evidență a populației, pentru alte cazuri de copii, a constatat că aprecierile de ordin public susținute de Guvern nu trebuiau să prevaleze asupra interesului privat de a înregistra copilul cu numele astfel ales.

În dreptul Uniunii Europene, ne vom referi la un $\mathrm{caz}^{16}$ care pune problema dreptului la nume în relația cu libertatea de circulație, libertate de bază în cadrul Uniunii Europene care se opune ca un stat membru al Uniunii să refuze recunoașterea numelui de familie al unui copil astfel cum fusese înregistrat pe teritoriul altui stat membru unde se născuse copilul.

Astfel, rezumând această cauză, vom reține că o familie de cetățeni germani s-au stabilit în Danemarca unde s-a și născut fiul lor. În virtutea legislației daneze în certificatul de naștere danez al copilului s-au înscris numele reunite ale părinților săi. Serviciile de stare civilă din Germania au refuzat, însă, recunoașterea numelui copilului înregistrat în Danemarca, aducând în favoarea refuzului lor argumentul potrivit căruia numele de familie al unei persoane este reglementat de legea statului al cărui cetățean este, iar dreptul german nu permite unui copil să poarte numele reunite ale părinților săi.

Curtea de Justiție a Uniunii Europene a fost solicitată, față de circumstanțele cauzei descrise mai sus, să stabilească dacă dispozițiile Uniunii se opun ca autoritățile dintr-un stat membru să refuze recunoașterea numelui de familie al unui copil care fusese înregistrat în alt stat membru. În răspunsul pe care l-a oferit ${ }^{17}$, Curtea a identificat o serie de inconveniente majore care se constituiau într-un obstacol în calea liberei circulații, incoveniente atât de ordin profesional cât și privat, care rezultă, în special, "din dificultatea de a beneficia, în statul membru ai căror resortisanți sunt, de efectele juridice ale actelor sau ale documentelor întocmite sub numele recunoscut într-un alt stat membru, a cărei cetățenie o au de asemenea"18.

Astfel, în raport de faptul că, în multe din acțiunile din viața cotidiană, se impune a se face dovada identității unei persoane, copilul risca să se confrunte cu îndoieli privind identitatea sa cauzate de diferența între numele din registrele autorităților daneze și cel care figurează în pașaportul său german. În plus, față de împrejurarea că acest copil locuia, la momentul la care s-a pronunțat Curtea, cu mama sa în Danemarca, dar se deplasa periodic în Germania la tatăl său care s-a stabilit acolo după divorț, exista inconvenientul ca, de-a lungul anilor, să beneficieze de o serie de documente între care să existe o divergență în privința numelui de familie.

Față de cele prezentate mai sus, a constatat Curtea ${ }^{19}$, "de fiecarea dată când numele utilizat într-o situație concretă nu corespunde cu cel care figurează în documentul prezentat cu titlu de dovadă a identității unei persoane, în special în vederea obținerii beneficiului unei perstații sau a unui drept oarecare ori a constatării reușitei la examene sau a validării unor capacități ori când numele care figurează în două documente prezentate 
împreună nu este același, o astfel de divergență de nume de familie poate provoca îndoieli cu privire la identitatea acestei persoane, precum și la autenticitatea documentelor prezentate sau la veridicitatea datelor pe care acestea le conțin".

\section{Dreptul copilului la cetățenie}

În literatura de specialitate ${ }^{20}$, pornind de la principiile din dreptul internațional, se admite că reglementarea cetățeniei este o problemă internă a fiecărui stat. Cu toate acestea, sunt de reținut ${ }^{21}$ câteva din principiile internaționale de care nu se poate face abstracție atunci când se examinează acest aspect al identității unei persoane: „orice persoană are dreptul la o cetățenie”; "nimeni nu poate fi lipsit în mod arbitrar de cetățenia sa sau de dreptul de a-și schimba cetățenia"; "orice persoană are dreptul la cetățenia statului pe teritoriul căruia s-a născut dacă nu are dreptul la alta".

La nivel de lămuriri terminologice, redăm o definiție pe care doctrina ${ }^{22}$ a dat-o cetățeniei române: „,acea calitate a persoanei fizice ce exprimă relațiile permanente socialeconomice, politice și juridice dintre persoana fizică și stat, dovedind apartenența sa la statul român și atribuind persoanei fizice posibilitatea de a fi titularul tuturor drepturilor și îndatoririlor prevăzute de Constituția și de legile României".

De asemenea, trebuie să avem în vedere faptul că în actualul context nu ne mai putem mărgini doar la analiza națională, ci în mod just trebuie să vorbim și despre o cetățenie europeană, "care vine astfel în completarea cetăţeniei naţionale, mai exact ea se suprapune, fără a se substitui, cetăţeniei naţionale, făcând posibilă exercitarea unora dintre drepturile cetăţeanului Uniunii pe teritoriul statului membru în care locuieşte" ${ }^{\prime 23}$.

Astfel, potrivit art.9 din Tratatul privind Uniunea Europeană „este cetățean al Uniunii orice persoană care are cetățenia unui stat membru" iar "cetățenia Uniunii nu înlocuiește cetățenia națională, ci se adaugă acesteia".

$\mathrm{Cu}$ referire la cetăţenia europeană, trebuie să menţionăm că prin hotărârea în cauza Grzelczyk ${ }^{24}$, Curtea de Justiţie a Uniunii Europene a ridicat statutul de cetăţean al Uniunii la nivel de statut fundamental al cetăţenilor statelor membre. În interpretarea acestor statuări ale Curţii, se concluzionează 25 asupra ideii de dezvoltare, de către Curtea de Justiţie a Uniunii Europene, a conceptului de „cetăţenie socială”, abandonându-se distincţia dintre cetăţeni activi şi non activi din punct de vedere economic. În acelaşi plan de idei s-a afirmat $^{26}$ că de la cetăţenia Uniunii Europene bazată pe paradigma economică a pieţei interne, Uniunea Europeană se îndreaptă spre o nouă paradigmă în organizarea legislaţiei, care se bazează, în esenţă, pe protejarea intereselor vitale ale cetăţenilor prin intervenţia legislaţiei Uniunii Europene.

Legat de aceste aspecte, în cele ce urmează, avem ocazia de a reda interpretarea Curții de Justiție a Uniunii Europene privitoare la dreptul de ședere acordat părintelui, resortisant al unui stat terț, care asigură întreținerea copiilor săi minori, ce s-au născut într-un stat membru și deci sunt cetățeni ai Uniunii. Această cauză este una de referinţă, având în vedere opiniile exprimate în literatura de specialitate internaţională ${ }^{27}$ potrivit cărora 
clarificarea limitelor impuse de legislaţia Uniunii Europene, în privinţa competenţelor statelor membre în definirea cetăţeniei de stat, a determinat o evoluţie cu un impact semnificativ asupra configuraţiei cetăţeniei Uniunii, astfel cum a fost ea înţeleasă iniţial.

Astfel, Curtea de la Luxemburg a stabilit ${ }^{28}$ că refuzarea dreptului de ședere al părintelui în a cărui îngrijire se afla copilul născut pe teritoriul unui stat membru lipsește copilul de „beneficiul efectiv al esenței drepturilor conferite de statutul lor de cetățean al Uniunii" întrucât are drept rezultat faptul că acel copil, cetățean al Uniunii este obligat să părăsească teritoriul Uniunii, alături de părinții lui.

în cauza în care Curtea a statuat astfel cum am redat mai sus, este vorba despre un cuplu de naționalitate columbiană care a solicitat azil în Belgia unde intrase pe baza unei vize emise de Ambasada Belgiei din Columbia. Autoritățile belgiene au respins cererile lor, astfel încât după foarte multe demersuri în fața autorităților cei doi soți au depus o nouă cerere de regularizare, întemeindu-se și pe o împrejurare nouă-aceea a nașterii celui de-al doilea copil al lor pe teritoriul statului belgian, fapt de natură a-i îndreptăți să se prevaleze de dispozițiile art.3 din Protocolul nr.4 la Convenția Europeană a Drepturilor Omului care se opun ca respectivul copil să fie constrâns să părăsească teritoriul statului a cărui cetățenie o are.

Analizând modul în care statele membre vor aplica interpretarea dată de Curte, sunt autori ${ }^{29}$ care consideră că cel puţin câteva state membre, fie ca o chestiune de preferinţă politică, fie din conservatorism juridic, vor susţine faptul că principiile cauzei Zambrano nu se aplică în afara tipului foarte specific al situaţiei. În sprijinul acestei opinii se face trimitere la orientarea autorităţilor olandeze care consideră că expulzarea unui părinte, în cazul în care celălalt părinte este capabil să îngrijească copiii, nu este în contradicţie cu Tratatul Uniunii deoarece copilul nu este forţat să plece.

Pentru a evita aplicările neunitare a principiilor din cauza Zambrano, se propune ${ }^{30}$ realizarea testului de proporţionalitate, de altfel testul standard al Uniunii Europene pentru măsurile naţionale care interferează cu drepturile cetăţenilor din statele membre. Cu alte cuvinte, ceea ce trebuie să primeze, în astfel de speţe, este examinarea măsurii în care decizia privind expulzarea părintelui/părinţilor are un efect disproporţionat asupra vieţii de familie a copilului şi calităţii şederii acestuia pe teritoriul Uniunii, al cărui cetăţean este.

Totodată, mai trebuie să menţionăm că, legat de cele statuate de Curtea de Justiţie a Uniunii Europene în cauza Zambrano, în doctrina internaţională s-au conturat două curente de opinie ${ }^{31}$. Astfel, pe de o parte s-a considerat inadecvată abordarea teleologică a Curţii referitoare la consecinţele deportării domnului Ruiz Zambrano-asupra drepturilor decurgând din cetăţenia europeană a copiilor săi, aceasta întrucât încalcă un domeniu clasic al competenţelor statelor membre, domeniu ce este sensibil din punct de vedere politic şi totodată pentru că au fost ignorate celelalte dispoziţii ale Tratatului care prevăd combaterea imigraţiei ilegale (art.79 din Tratatul privind funcţionarea Uniunii Europene). Pe de altă parte s-a susţinut că evoluţia Curţii în materie de cetăţenie a Uniunii Europene este atât legală cât şi justificabilă din punct de vedere politic. În fundamentarea acestei teze s-a avut în vedere şi faptul că aplicarea dispoziţiilor citate din Tratatul privind funcţionarea Uniunii Europene ar fi părut exagerată, deoarece imigraţia ilegală nu este atât de mult încurajată de 
extinderea dreptului de şedere derivat pentru părinţii cetăţenilor Uniunii, ci, în primul rând, de obţinerea automată a naţionalităţii ${ }^{32}$. Ceea ce s-a impus pentru concluziile Curţii a fost faptul că negarea dreptului de şedere pentru domnul şi doamna Zambrano ar fi avut drept rezultat privarea copiilor de o şansă realistă de a-şi folosi drepturile în calitate de cetăţeni ai Uniunii şi de a-şi dezvolta identitatea ca cetăţeni europeni, ceea ce ar fi însemnat, totodată, şi faptul că aceştia ar fi suportat costul acţiunilor ilegale ale părinţilor, fapt ce ar fi depăşit limitele raţiunii combaterii imigraţiei ilegale ${ }^{33}$.

De asemenea, mai sunt autori ${ }^{34}$ care apreciază că nu este surprinzătoare pronunţarea în favoarea drepturilor de şedere ale părinţilor aflaţi într-un caz precum cel descris mai sus, având în vedere şi art. 8 al Convenţiei Europene a Drepturilor Omului care a fost invocat în mod regulat de Curte pentru a sublinia faptul că separarea membrilor de familie trebuie să fie justificată corespunzător.

În sistemul Convenției Europene a Drepturilor Omului, se consideră încălcare a art.8 din Convenție - care garantează dreptul la viață privată, refuzul discriminatoriu al acordării cetățeniei. De exemplu ${ }^{35}$, s-a considerat refuz discriminatoriu de a acorda cetățenia acela care a vizat un copil născut în afara căsătoriei. Curtea a reamintit și cu ocazia acestei analize că o diferență de tratament de genul celei descrise este discriminatorie dacă nu are o justificare rezonabilă și obiectivă, nu urmărește un scop legitim și nu există proporționalitate între măsura adoptată și scopul legitim presupus a fi urmărit.

\section{Dreptul copilului de a-şi stabili identitatea biologică}

Un element de bază pentru statutul civil al persoanei fizice îl constituie dreptul de a-și cunoaște ascendența, de a-și stabili, cu alte cuvinte, filiația ${ }^{36}$. Importanța stabilirii filiației rezidă și în efectele pe care aceasta le produce, efecte legate de nume, drepturi şi îndatoriri părinteşti, vocație succesorală, obligație de întreținere ${ }^{37}$, etc.

În optica instanței de contencios european procedurile legate de paternitate intră sub incidenţa art. 8 al Convenției Europene a Drepturilor Omului care protejează nu numai viaţa „de familie”, dar şi viaţa „privată”, ce include aspecte legate de identitatea fizică şi socială a unei persoane, aspecte care conferă fiecărui om posibilitatea de a stabili detaliile identităţii sale de fiinţă umană.

Curtea Europeană a Drepturilor Omului a reținut ${ }^{38}$ că persoanele care caută să-și stabilească identitatea ascendenților lor au un interes vital protejat de Convenție în a obține informații necesare pentru a descoperi adevărul despre un important aspect al identității lor. În cauza citată, „imposibilitatea de a obține efectuarea unei analize ADN a unor țesuturi din rămășițele pământești ale presupusului tată biologic al reclamantului a fost considerată o ingerință disproporționată cu dreptul la identitate, neputând fi justificată prin protecția memoriei defunctului și intangibilitatea corpului acestuia" ${ }^{39}$.

O altă problemă ce se poate ridica, în acțiunile ce privesc filiația, este aceea a stabilirii paternității copilului împotriva voinței presupusului tată, având în vedere refuzul acestuia de a se prezenta pentru efectuarea testelor biologice. Cu această ocazie vom vorbi despre un 
„conflict" între dreptul copilului de a-și cunoaște identitatea, ca o componentă a dreptului la viață privată și de familie și dreptul presupusului tată de a refuza să fie supus unor teste medicale împotriva voinței sale ${ }^{40}$. În soluționarea acestui „conflict”, principiul aplicat de Curtea de la Strasbourg ${ }^{41}$ este acela al proporționalității protecției intereselor din cauză.

Astfel, în cauza Mikulić/Croația la care ne raportăm cu prilejul acestei analize, Curtea a constatat că procedurile aplicabile la nivel intern, în Croația, nu erau de natură să asigure un echilibru just între dreptul solicitantului de a i se elimina orice dubiu cu privire la identitatea personală, fără întârzieri inutile și nejustificate și dreptul presupusului tată de a refuza să fie supus testelor ADN. În consecință, ineficiența mijloacelor aflate la îndemâna solicitantului l-au plasat pe acesta într-o situație de incertitudine cu privire la identitatea sa, prelungită nejustificat, autoritățile croate eșuând să-și îndeplinească obligația pozitivă ce le revenea în cadrul asigurării dreptului la viață privată și de familie prevăzut de art. 8 al Convenției.

Și într-o cauză înaintată împotriva României ${ }^{42}$, Curtea a constatat faptul că "dreptul intern nu prevede nicio măsură care să permită obligarea părţii pârâte să se supună ordinelor instanţelor şi să accepte să efectueze teste de paternitate, ceea ce poate să corespundă necesităţii de a proteja terţii, excluzând posibilitatea de a-i constrânge pe aceştia să se supună oricărui tip de examen medical, în special teste ADN". Cu toate acestea, în Hotărârea pronunțată în speță, Curtea a reamintit faptul că, pentru a soluţiona o acţiune care are ca scop stabilirea paternităţii, instanţele trebuie să ţină seama de interesul superior al copilului și să respecte un echilibru just între dreptul reclamantului minor de a i se proteja interesele în procedura care avea ca scop risipirea incertitudinii cu privire la identitatea sa şi dreptul tatălui său presupus de a nu participa la procedură şi de a nu se supune unor teste de paternitate.

Cuceririle științei aduc în discuție și aspecte mai controversate în materia stabilirii filiației. În acest sens vom face referire la recunoașterea legăturii de filiație între copiii concepuți legal prin gestația pentru altul și părinții de intenție ${ }^{43}$.

Speța care a prilejuit această analiză vizează un cuplu de francezi care după mai multe încercări nereușite de fertilizare in vitro au decis să recurgă la ajutorul unei mame surogat, realizând procedura în California, Statele Unite ale Americii. Conform legislației existente pe tărâm american cei doi soți francezi au obținut o hotărâre care indica că la mențiunile de pe certificatul de naștere al gemenilor născuți prin această procedură vor fi trecuți ei, în calitate de părinți. Cu toate acestea, autoritățile consulare franceze au refuzat să transcrie certificatele de naștere, motivându-și refuzul prin argumentul că hotărârea obținută astfel în străinătate este incompatibilă cu ordinea publică de drept internațional franceză. Având în vedere cele prezentate mai sus, cei doi soți s-au plâns la Curtea Europeană a Drepturilor Omului că, în detrimentul interesului superior al copiilor lor, nu au posibilitatea de a obține în Franța recunoașterea filiației legal stabilite în străinătate.

Examinând această cerere, Curtea a recunoscut ${ }^{44}$ că statelor trebuie să li se acorde, de principiu, "o marjă de apreciere, în ce privește nu numai decizia de a autoriza sau nu acest mod de procreare, ci în egală măsură și cea de a recunoaște sau nu o legătură de filiație între copiii 
concepuți legal prin gestația pentru altul în străinătate și părinții de intenție". Totuși, luând în considerare faptul că filiația este un aspect esențial al identității persoanelor, marja de apreciere amintită ar trebui redusă pentru a asigura un just echilibru între interesele Statului și cele ale persoanelor direct vizate de măsurile pe care le adoptă Statul.

Pentru copiii gemeni născuți în atari condiţii, Curtea a constatat că aceștia se află într-o situaţie de incertitudine juridică de natură a crea consecinţe negative asupra definirii propriei lor identităţi, prin refuzul autorităţilor franceze de a le transcrie certificatele de naştere emise în altă ţară, în registrele lor naţionale de stare civilă.

În fundamentarea soluției mai sus redate, s-au reţinut o serie de inconveniente pe care urmau să le suporte copiii, după cum urmează: "astfel, nedispunând de acte de stare civilă franceze sau de livrete de familie franceze, reclamanții sunt constrânși să prezinte actele de stare civilă americane - netranscrise - însoțite de o traducere legalizată, de fiecare dată când accesul la un drept sau la un serviciu presupune dovada filiației, și sunt confruntați uneori cu o atitudine de suspiciune sau cel puțin cu lipsa de înțelegere din partea persoanelor cărora li se adresează. Ei amintesc, în acest sens, de dificultățile intervenite cu ocazia înscrierii celor de-a treia și de-a patra reclamante în sistemul de securitate socială, la cantina școlii sau la un centru de activități în aer liber și a depunerii cererilor de ajutor financiar la oficiul de alocații familiale.Mai mult, faptul că cei doi copii nu au un raport de filiație nici cu primul reclamant, nici cu a doua reclamantă în dreptul francez, are drept consecință, cel puțin în prezent, lipsa recunoașterii naționalității franceze pentru acestea"45.

Ceea ce trebuie subliniat cu privire la această speță este că, remarcând existenţa unei legături biologice cu tatăl, Curtea se referă la importanţa unei relaţii biologice ca parte a identităţii unei persoane, afirmând că este contrar intereselor unui copil să-l priveze de o legătură juridică de acest fel.

Se observă ${ }^{46}$ că instanţa de contencios european nu precizează că o asemenea legătură de familie trebuie să fie stabilită şi în cazul soţului/soţiei părintelui biologic, în ipoteza în care aceasta din urmă nu are o relaţie biologică cu copilul. De aici concluzia ${ }^{47}$ potrivit căreia Curtea nu va cenzura neapărat decizia unei ţări de a recunoaşte doar relaţia stabilită în străinătate faţă de unicul părinte biologic (cel mai adesea tatăl), mai ales că acest lucru nu aduce atingere posibilită̌tii ca soţia să stabilească o relaţie de familie urmare a adopţiei. De altfel, în acest context de analiză, s-a remarcat ${ }^{48}$ faptul că tările care acceptă procedura reproducerii prin mamă surogat solicită, cel mai adesea, utilizarea gameţilor de la cel puţin un membru al cuplului, ca în cazurile din Regatul Unit şi Africa de Sud şi de la cei doi membri în cazurile din Olanda şi Rusia şi refuză să recunoască ca fiind surogaţie o sarcină heterologă totală, această din urmă practică semănând mai mult cu vânzarea unui copil decât cu o reproducere asistată medical.

În esenţă, se reţine ${ }^{49}$, cu privire la cele decise în cauza Mennesson împotriva Franței, că deşi Curtea recunoaşte statelor membre posibilitatea de a interzice procedura surogaţiei, totuşi limitează impactul acestei interdicţii, mai ales pentru acele cazuri unde există o legătură biologică cu unul dintre părinţi. Procedând de maniera aceasta, Curtea Europeană a Drepturilor Omului se asigură că efectele refuzării surogaţiei sunt limitate dar 
mai ales conforme cu respectarea art.8 din Convenţia Europeană a Drepturilor Omului ${ }^{50}$. De asemenea, se apreciază ${ }^{51}$ că hotărârea Menesson împotriva Franţei este un alt exemplu de cauză care contribuie la extinderea conţinutului art.8 al Convenţiei Europene a Drepturilor Omului, ceea ce reflectă schimbarea culturii occidentale, făcând din autonomia individuală o nouă valoare fundamentală.

Nu putem finaliza studiul nostru fără a menționa și faptul că, în lumina jurisprudenţei dezvoltate de Curtea Europeană a Drepturilor Omului, doctrina ${ }^{52}$ a evidenţiat şi câteva limitări a dreptului la identitate personală. Astfel, într-o cauză în care reclamantul nu a dorit să se stabilească că este fiul defunctului "nici pentru a obține securitatea emoțională ce rezultă din faptul de a se considera că face parte dintr-o anumită familie, nici pentru a crea legături cu membrii în viață ai familiei persoanei decedate, ori pentru a înlătura orice dubii privitoare la identitatea sa personală, ci a urmărit numai să obțină succesiunea defunctului prin înlăturarea unicului moștenitor legal al acestuia", Curtea Europeană a Drepturilor Omului a stabilit că dispozițiile art.8 din Convenție nu au fost încălcate în cauza dată53 .

\section{Concluzii}

După cum s-a afirmat în literatura de specialitate ${ }^{54}$, o constanţă a vieţii de familie este reprezentată de respectarea principiului interesului superior al copilului, acest principiu fiind opozabil deopotrivă părinţilor dar şi autorităţilor care au competenţe de a lua măsuri în legătură cu persoana copilului.

Importanţa protejării intereselor copilului a fost relevată, o dată în plus, şi cu prilejul analizei pe care am realizat-o cu privire la respectarea dreptului la identitate al copilului. Examenul jurisprudenţial întreprins la nivelul Curţilor europene conturează următoarele concluzii:

- în sistemul Convenţiei Europene a Drepturilor Omului, raţionamentul Curţii se centrează pe realizarea unui echilibru just între interesele copilului legate de identitatea sa, interesele persoanelor terţe vizate de soluţiile adoptate de autorităţi pentru respectarea drepturilor copilului, respectiv interesul general. În cele mai multe cazuri, cel care a prevalat a fost interesul copilului. Cu toate acestea, la nivel conclusiv nu se poate absolutiza acest principiu, admiţându-se fapul că există anumite limite în valorificarea dreptului supus examinării noastre;

- la nivelul Uniunii Europene, deşi nu am identificat, în această materie, o jurisprudenţă la fel de bogată ca cea a Curţii Europene a Drepturilor Omului, ceea ce reţinem este faptul că statele membre se bucură de recunoaşterea unei marje de apreciere proprii, condiţia de respectat fiind aceea de a nu intra în conflict cu principiile dreptului unional, respectiv cu principalele libertăţi recunoscute la nivelul Uniunii Europene. De asemenea abordarea utilă este cea a realizării testului de proporţionalitate, acesta fiind principiul obiectiv de aplicat pentru a şti dacă măurile naţionale adoptate ating substanţa drepturilor de care se bucură cetăţenii europeni. 
* Prof. univ. dr., Facultatea de Drept, Universitatea Transilvania Brașov, ioana.nicolae@unitbv.ro

${ }^{* *}$ Asist. univ. dr., Facultatea de Drept, Universitatea Transilvania Brașov, bianca.tarata@gmail.com

${ }^{1}$ A. Bacaci, V.C. Dumitrache, C.C. Hageanu, Dreptul familiei. Ediția 7. În reglementarea Noului Cod civil, Editura C.H. Beck, București, 2012, p.323

2 Această apreciere se conturează și prin raportare la art.20 și 148 din Constituția României, respectiv art.4, 5 Cod civil

${ }^{3}$ Pentru opinia potrivit căreia jurisprudenţa CEDO în materia protecţiei copilului este un reper important pentru orientarea rgelementărilor şi a jurisprudenţei naţionale, a se vedea M. Avram, Drept civil. Familia, Editura Hamangiu, București, 2013, p.453

4 în acest sens, a se vedea, A. Drăghici, I. Didea, R. Duminică, The Right of Children to Know their Parents - a Constitutive Element of the Child's Identity, Acta Universitatis Danubius.Juridica, vol. 9, no. $1 / 2013$, p.116

${ }^{5}$ C. Bîrsan, Convenția europeană a drepturilor omului. Comentariu pe articole. Vol. I. Drepturi și libertăți, Editura All Beck, București, 2005, p.605

${ }^{6}$ Art. 8 al Convenției Europene a Drepturilor Omului are următorul conținut normativ: "1. Orice persoană are dreptul la respectarea vieţii sale private şi de familie, a domiciliului său şi a corespondenţei sale. 2 . Nu este admis amestecul unei autorităţi publice în exercitarea acestui drept decât în măsura în care acesta este prevăzut de lege şi constituie, într-o societate democratică, o măsură necesară pentru securitatea naţională, siguranţa publică, bunăstarea economică a ţării, apărarea ordinii şi prevenirea faptelor penale, protecţia sănătăţii, a moralei, a drepturilor şi a libertăţilor altora".

${ }^{7}$ Astfel cum a fost publicată în Jurnalul Oficial al Uniunii Europene, C 202, 7 iunie 2016

${ }^{8}$ A se vedea, în acest sens, A. Drăghici, Protecția juridică a drepturilor copilului, Editura Universul Juridic, București, 2013, p.103

${ }^{9}$ Lege privind protecția și promovarea drepturilor copilului, republicată în Monitorul Oficial al României, Partea I nr.159/05.03.2014, cu modificările și completările ulterioare

${ }^{10}$ E. Poenaru, Drept civil. Teoria generală. Persoanele, Editura All Beck, București, 2002, p.329

${ }^{11}$ E. Chelaru, Drept civil. Persoanele. În reglementarea Noului Cod civil. Ediția a 3-a, Editura C.H. Beck, București, 2012, p.80, T. Prescure, R. Matefi, Drept civil. Partea generală. Persoanele, Editura Hamangiu, București, 2012, p. 262 și urm.

12 E. Chelaru, op. cit., p. 81

${ }^{13}$ A. Drăghici, op. cit., p.108

${ }^{14}$ A se vedea, în acest sens, C. Bîrsan, op. cit., p.604 și cauza citată acolo-Guillot c. Franței

${ }^{15}$ Hotărârea CEDO din 6 septembrie 2007 în cauza Johansson/Finlanda (cererea nr.10163/02)

${ }^{16}$ Cauza C-353/06, Stefan Grunkin și Dorothee Regina Paul

${ }^{17}$ Hotărârea Curții de Justiție a Uniunii Europene (Marea Cameră) din data de 14 octombrie 2008, EU:C:2008:559

${ }^{18}$ Paragraful 23 din Hotărârea cit. supra.

${ }^{19}$ Paragraful 28 din Hotărârea cit. supra.

20 D.C. Dănișor, Constituția României comentată. Titlul I. Principii generale, Editura Universul Juridic, București, 2009, p.207

${ }^{21}$ A se vedea, în acest sens D.C. Dănișor, op. cit., p.207

22 I. Muraru, S. Tănăsescu, Drept constituțional și instituții politice, Ediția a IX-a revăzută și completată, Editura Lumina Lex, București, 2001, p.137

${ }^{23}$ R. Duminică, A. Drăghici, A Short Analysis of Children's Right to a Citizenship as a Constitutive Element of Their Identity, Valahia University Law Study, Supplimentary Issue, 2013, pp. 141-147 
24 Hotărârea Curţii de Justiţie a Uniunii Europene din 20 septembrie 2001, în cauza C-184/99, EU:C:2001:458, paragraful 31

${ }^{25}$ Wiesbrock, Anja, Union Citizenship and the Redefinition of the 'Internal Situations' Rule: The Implications of Zambrano (2011). German Law Journal, Vol. 12, pp. 2083-2084, articol consultat în baza de date SSRN: https://ssrn.com/abstract=2117197 (accesată la 10.04.2017)

${ }^{26}$ Kochenov, Dimitry and Plender, Sir Richard, EU Citizenship: From an Incipient Form to an Incipient Substance? The Discovery of the Treaty Text (2012). 37 European Law Review 369 (2012), p.395, articol consultat în baza de date SSRN: https://ssrn.com/abstract=2137680 (accesată la 10.04.2017)

${ }^{27}$ Hailbronner, Michaela and Iglesias Sánchez, Sara, The European Court of Justice and Citizenship of the European Union: New Developments Towards a Truly Fundamental Status. Vienna Journal on International Constitutional Law, Vol. 5, Issue 4, December 2011, p.500, lucrare consultatǎ în baza de date SSRN: https://ssrn.com/abstract=1927198 (accesată la 10.04.2017)

${ }^{28}$ Hotărârea Curții de Justiție a Uniunii Europene (Marea Cameră) din 8 martie 2011 în cauza C34/09, Ruiz Zambrano, EU:C:2011:124

${ }^{29}$ Davies, Gareth T., The Family Rights of European Children: Expulsion of Non-European Parents (February 10, 2012). EUI Working Paper No. RSCAS 2012/04, pp.8-9 lucrare consultată în baza de date SSRN: https://ssrn.com/abstract=2002706 (accesată la 10.04.2017)

30 Davies, Gareth T., op. cit., p.11, lucrare consultată în baza de date SSRN: https://ssrn.com/abstract=2002706 (accesată la 10.04.2017)

${ }^{31}$ Cele două teze au fost expuse în lucrarea: Hailbronner, Michaela and Iglesias Sánchez, Sara, op. cit., p.520, lucrare consultată în baza de date SSRN: https://ssrn.com/abstract=1927198_(accesată la 10.04.2017)

32 Hailbronner, Michaela and Iglesias Sánchez, Sara, op. cit., p.521-522

33 Idem

34 Davies, Gareth T., Op. Cit., p.1, lucrare consultată în baza de date SSRN: https://ssrn.com/abstract=2002706 (accesată la 10.04.2017)

${ }^{35}$ Hotărârea CEDO din 11 ianuarie 2012 în cauza Genovese/Malta (cererea nr.53124/09)

${ }^{36}$ Filiaţia este formă a rudeniei, fiind socotită ca „punct de pornire al acesteia”- în acest sens M. Avram, op. cit., p.350

37 În acest sens a se vedea M. Avram, op. cit., p.404; M. M. Oprescu, M.A. Oprescu, M. Șcheaua (coord.), Noul Cod civil comentat și adnotat. Despre familie. Art.258-534, Editura Rosetti International, 2015, p.318

${ }^{38}$ Hotărârea CEDO din 13 iulie 2006 în cauza Jäggi/Elveția (cererea nr.58757/00)

39 Pentru considerații asupra Hotărârii CEDO în cauza Jäggi/Elveția, a se vedea B.A. Selejan-Guțan, Protecția europeană a drepturilor omului, ediția 4, Editura C.H. Beck, 2011, lucrare consultată în baza de date Legalis (accesată la 10.03.2017)

${ }^{40}$ Pentru aceste referiri la jurisprudența relevantă CEDO, a se vedea G.C. Frențiu, Dreptul familiei. Practică judiciară conform noului Cod civil. Jurisprudență CEDO, Editura Hamangiu, 2013, p.183-184

41 În acest sens Hotărârea CEDO din 7 februarie 2002 în cauza Mikulić/Croația

42 Cauza A.M.M. împotriva României (cererea nr.2151/10)

${ }^{43}$ Cauza Mennesson împotriva Franței (cererea nr.65192/11)

${ }^{44}$ Hotărârea CEDO din 26 iunie 2014, cauza Mennesson/Franța (cererea nr.65192/11), paragraful 44

${ }^{45}$ Hotărârea CEDO din 26 iunie 2014, cauza Mennesson/Franța (cererea nr.65192/11), paragrafele 53 și 54 
46 Puppinck, Gregor and Hougue, Claire de La, ECHR: Towards the Liberalisation of Surrogacy: Regarding the Mennesson v. France and Labassee v. France Cases (N65192/11 \& $\left.N^{\circ} 65941 / 11\right)$. Revue Lamy Droit Civil, nr. 118, September 2014. p.78., articol consultat în limba engleză în baza de date SSRN: https://ssrn.com/abstract=2500075 (accesată la 10.04.2017)

47 Puppinck, Gregor and Hougue, Claire de La, op. cit., în baza de date SSRN: https://ssrn.com/abstract=2500075 (accesată la 10.04.2017)

48 Idem

49 Ibidem

${ }^{50} \mathrm{Ibidem}$

51 Ibidem

52 C. Bîrsan, Convenția europeană a drepturilor omului, ediția 2, Editura C.H. Beck, 2010 (lucrare accesată în baza de date Legalis, la 10.03.2017)

53 Cauza Haas/Olanda (cererea nr.36983/97) astfel cum a fost amintită în C. Bîrsan, op. cit. ediția 2, 2010, (accesată în baza de date Legalis, la 10.03.2017)

${ }^{54}$ E. Florian, Dreptul familiei. Ediţia a 4-a, Editura C.H. Beck, 2011, p.11 